\title{
Effect of the infection with Eimeria acervulina, E. maxima and E. tenella on pigment absorption and skin deposition in broiler chickens ${ }^{\#}$
}

\author{
Efecto de la infección con Eimeria acervulina, E. maxima y E. tenella en la absorción \\ y el depósito del pigmento en la piel de pollos de engorde \\ N J Frade-Negrete ${ }^{a}$, X Hernández-Velasco ${ }^{a *}$, B Fuente-Martínez ${ }^{b}$, M Quiroz-Pesina ${ }^{c}$, \\ E Ávila-González ${ }^{\mathrm{b}}, \mathbf{G}$ Tellez $^{\mathrm{d}}$
}

\begin{abstract}
Two experiments were conducted in broiler chickens from 21 to $49 \mathrm{~d}$ of age to evaluate the plasmatic level, deposition, and digestibility of xanthophylls (XA) from marigold flower (Tagetes erecta) after infection with vaccine strains of Eimeria spp. In Experiment 1, 432 birds were assigned to 4 treatments: 1) non-infected control; 2) $8.32 \times 10^{4}$ sporulated Eimeria oocysts (SEO)/bird; 3) $17.82 \times 10^{4} \mathrm{SEO} /$ bird, and 4) $49.92 \times 10^{4} \mathrm{SEO} /$ bird. In Experiment 2, 400 broilers were assigned to 4 treatments: 1) non-infected control; treatments 2 to 4 were challenged with $8.32 \times 10^{4} \mathrm{SEO} /$ bird. The birds received 85, 108,141, and 162ppm of total dietary XA from d 35 to 49 for treatments 1 to 4 , respectively. Both experiments contained 4 replications (2/sex) per treatment. In Experiment 1, the SEO dose was associated with the reduction in body weight gain (BWG), skin yellowness units (b*), and plasma xanthophylls (PX). In both sexes, $b^{*}$ increased by $1.36 / \mathrm{d}$ of XA consumption. For every $10^{4} \mathrm{SEO}, \mathrm{PX}$ decreased by $0.8 \mu \mathrm{g} / \mathrm{ml} / \mathrm{d}$, and $0.06 \mathrm{~b}^{*}$. In Experiment 2 , no difference was detected in PX or $\mathrm{b}^{*}$ at $49 \mathrm{~d}$ between treatments. XA digestibility decreased by 15 units in the infected birds. Results suggest that XA digestion and absorption are similar between males and females. However, females have a greater ability for skin XA deposition. After a mild Eimeria spp. infection, it is possible to achieve adequate skin yellowness (SY) levels if the infected birds are treated immediately and receive at least $62 \mathrm{mg}$ of dietary XA/bird for $14 \mathrm{~d}$.
\end{abstract}

Key words: broiler chicken, Eimeria, plasma xanthophyll, skin pigment.

RESUMEN. Se evaluó el nivel plasmático, depósito cutáneo y digestibilidad de xantófilas (XA) de flor de cempasúchil (Tagetes erecta) en pollos infectados por vía oral con cepas vacunales de Eimeria spp. En el experimento 1 se probaron diferentes dosis infectantes: 1) testigo no infectado; 2) 8,32 x $10^{4}$ ooquistes esporulados de Eimeria (OEE)/ave; 3) 17,82 x 104 OEE/ave, y 4) 49,92 x $10^{4} \mathrm{OEE} / \mathrm{ave}$; en el experimento 2 se utilizó una dosis infectante y diferentes dosis de pigmento en la dieta: 1) testigo no infectado; y los tratamientos 2 a 4 se desafiaron con 8,32 x $10^{4}$ OEE/ave, las aves fueron tratadas, y se proporcionaron 85, 108, 141, o $162 \mathrm{ppm}$ de XA totales en la dieta en los grupos 1 a 4, del día 35 al 49 de edad. Cada experimento tuvo 4 réplicas (2/sexo) por tratamiento. En el Experimento 1 la dosis de OEE se asoció con la reducción en la ganancia de peso, unidades de amarilleamiento cutáneo (b*), y nivel de xantófilas plasmáticas (XP). Por cada $10^{4} \mathrm{OEE}$ las XP disminuyeron 0,80 mg/ml/d, y 0,06 en b*. En el Experimento 2 la digestibilidad de las XA disminuyó 15 unidades en las aves infectadas y los niveles de XP o b* fueron similares entre tratamientos al final de la prueba. Se sugiere que la digestión y absorción de XA es entre sexos, pero la hembra deposita más XA cutáneas. Después de una infección moderada por Eimeria es posible lograr niveles comercializables de amarilleamiento cutáneo (SY) mediante un tratamiento y al menos $62 \mathrm{mg}$ de XA/ave/14 d.

Palabras clave: pollo de engorda, Eimeria, xantófilas plasmáticas, pigmento cutáneo.

\section{INTRODUCTION}

In China, Spain, Italy, Mexico and Peru, amongst other countries, the consumer demands chicken with yellow skin

Accepted: 15.10 .2015 .

apepartamento de Medicina y Zootecnia de Aves, Facultad de Medicina Veterinaria y Zootecnia, Universidad Nacional Autónoma de México, México Distrito Federal.

${ }^{\mathrm{b}}$ Centro de Enseñanza, Investigación y Extensión en Producción Avícola, Facultad de Medicina Veterinaria y Zootecnia, Universidad Nacional Autónoma de México, México Distrito Federal.

'Vepinsa S.A. de C.V., Los Mochis, Sinaloa, Mexico.

${ }^{\mathrm{d} D e p a r t m e n t ~ o f ~ P o u l t r y ~ S c i e n c e, ~ U n i v e r s i t y ~ o f ~ A r k a n s a s, ~ F a y e t t e v i l l e, ~ U S A . ~}$

\#This project was sponsored by Programa de Apoyo a Proyectos de Investigación e Innovación Tecnológica (PAPIIT) de la Dirección General de Apoyo al Personal Académico (DGAPA); Proyecto IN203910-3, Universidad Nacional Autónoma de México.

*Corresponding author: X Hernández-Velasco, Av. Universidad 3000, Col. Ciudad Universitaria. Del. Coyoacán, CP. 04510. México, D.F., México; xochitl_h@yahoo.com pigmentation. Since skin pigmentation is associated with health status and product freshness (Breithaupt 2007, Liu et al 2008, Hernandez-Velasco et al 2014), there is a large volume of whole chicken or parts commercialized with the skin (Baker and Günther 2004). The inclusion level of dietary pigment for broiler chickens varies depending upon the company, region, and country.

Commercial competition and shorter grow-out periods require the use of high concentrations of dietary xanthophylls (XA), which may represent 8 to $10 \%$ of the diet cost. In Mexico, it is very typical to feed $80 \mathrm{ppm}$ or more in the last 3 or 4 weeks of the grow-out (Muñoz-Díaz et al 2012), with XA consumption per bird between 240 and $500 \mathrm{mg}$. These levels usually yield skin pigmentation levels of at least 22 skin yellownes units ( $\left.b^{*}\right)$ in live birds, and greater than $47 b^{*}$ in cold carcasses, as measured in the lateral apterial pectoral area (Muñoz-Díaz et al 2012, Hernandez-Velasco et al 2014). 
Amongst dietary carotenoids, in particular the XA (dihydroxycarotenoids) lutein and zeaxanthin are the components of major economic interest in Aztec marigold flower (Tagetes erecta) extract that are associated with natural yellow coloration in chicken skin and fat (Hadden et al 1999, Kotake-Nara and Nagao 2011). In addition to their pigmenting properties, XA are also antioxidants and provide natural UV protection, thus XA might be helpful to maintain healthy vision and skin. Therefore, inclusion of natural pigments in diets for poultry destined for human consumption may pose additional value to the health-conscious consumer (Baker and Günther 2004, Kijlstra et al 2012).

Skin pigmentation depends upon various factors such as: XA dose and consumption time, dietary nutritive quality, bird's sex, bird health status, and slaughter processing conditions, among others (Britton et al 1998). From the diseases that influence skin pigmentation, coccidiosis is perhaps one of the most frequent and costly infections that affect the poultry industry globally (Ruff and Fuller 1975, Tyczkowski and Hamilton 1991). The severity of the coccidiosis effect on skin pigmentation will depend on the Eimeria strain and virulence, immune status of the bird, and other complicating factors. E. acervulina and E. maxima produce a significant reduction in plasma carotenoids (Ruff and Fuller 1975, Sharma and Fernando 1975, Ogbuokiri and Edgar 1986, Tyczkowski and Hamilton 1991). These infections are sometimes associated with lower body weight gain (BWG) that is a consequence of poor nutrient absorption due intestinal sloughing and villi shortening (Allen 1987). Plasma xanthophylls (PX) concentrations have proven to be sensitive indicators of the severity of Eimeria infections compared to other criteria such as live weight, macroscopic lesion scoring, and the number of oocysts shed in feces (Conway et al 1990).

Despite the economic impact of skin pigmentation in broiler chickens across various countries, and the fact that coccidiosis is the main infectious disease that affects it, there are very few studies, if any, that quantify the effect of Eimeria spp. infections on broiler skin pigmentation and how it may be influenced by bird's sex. Therefore, the objectives of the current study were to evaluate the effect of Eimeria spp infection on XA absorption and deposition and ileal digestibility in broiler chickens, and to assess the recovery in skin pigmentation in broilers exposed to a mild coccidia infection.

\section{MATERIAL AND METHODS}

\section{FACILITIES}

The experiments were conducted at the Center for Research, Education, and Extension in Poultry Production (CEIEPAv) and the diagnostic laboratory of the Avian Medicine Department (DMZA) of the College of Veterinary
Medicine and Zootechnics (FMVZ), at the National Autonomous University of Mexico (UNAM).

\section{EXPERIMENTAL BIRDS}

Two experiments were conducted with sexed Ross 308 broiler chickens. The birds were separated by sex, and raised from 0 to $21 \mathrm{~d}$ of age in floor pens in an open-sided house. The experiments were conducted in accordance with the Guidelines of the Institutional Animal Care and Use Committee of the FMVZ, at the UNAM (CICUAEFMVZ-UNAM). For both experiments, the birds were individually weighed at $21 \mathrm{~d}$ of age such that each pen had similar weight and weight distribution.

FEED

Diets were based on sorghum-soybean meal, and were formulated for three feeding phases: starter, 0-10 d; grower, 11-20 d; and finisher, 21-49 d of age. The diets contained meat and bone meal, and were designed to meet the nutrient specifications as recommended by the primary breeder (Aviagen 2007 ${ }^{1}$ ). Feed and water were provided ad libitum in a mash form. During the starter phase, all birds received 125 ppm of nicarbazine, and 100 ppm of sodium monensin during the grower phase, and only treatment one in the finisher phase in Experiment 1. In the finisher phase, all birds received 85 ppm of dietary XA from Aztec marigold flower.

\section{EXPERIMENTAL DESIGN}

Experiment 1. Four hundred and thirty two 21-d-old Ross 308 sexed broiler chickens were randomly assigned to 4 treatments: 1) Non-infected control; 2) $8.32 \times 10^{4}$ sporulated Eimeria oocysts (SEO) per bird; 3) $17.82 \times 10^{4}$ SEO per bird; and 4) $49.92 \times 10^{4} \mathrm{SEO}$ per bird. Treatments contained 4 replications (2 replications of males and 2 of females) of 27 birds each. All birds received 85 ppm of dietary XA from Aztec marigold flower from 21 to $49 \mathrm{~d}$ of age.

Experiment 2. Four hundred 21-d-old Ross 308 sexed broiler chickens were randomly assigned to 4 dietary treatments containing 4 replications ( 2 replications of males and 2 of females) of 25 birds each. Treatments were designed as follows: 1) Non-infected control +85 ppm of dietary XA; 2) $8.32 \times 10^{4}$ SEO/bird + additional 23ppm of XA (108 ppm total); 3) $8.32 \times 10^{4} \mathrm{SEO} / \mathrm{bird}$ + additional 56 ppm of XA (141 ppm total); and 4) 8.32 x $10^{4} \mathrm{SEO} /$ bird + additional $77 \mathrm{ppm}$ of dietary XA (162 ppm total). At 28, 29, 38, and $39 \mathrm{~d}$ of age, all birds were treated with toltrazuril at $7 \mathrm{mg} / \mathrm{kg}$ of body weight (BW)

\footnotetext{
1 Aviagen, 2007. Broiler nutrition specification Ross 308. Aviagen, Huntsville, Alabama. Web MD. http://en.aviagen.com/assets/ Tech_Center/Ross_Broiler/Ross_308_Broiler_Nutrition_Spec.pdf. Accessed September 2014.
} 
via drinking water. The infected birds (treatments 2, 3, and 4) received sodium monensin from 36 to $49 \mathrm{~d}$ of age. All birds received $85 \mathrm{ppm}$ of XA from 21 to $36 \mathrm{~d}$ of age. The infected treatments received higher levels of dietary XA from 36 to $49 \mathrm{~d}$ of age, at the levels indicated above.

\section{CHALLENGE}

In both experiments, at $21 \mathrm{~d}$ of age, the birds from treatments 2, 3, and 4 received an inoculum containing vaccine strains of Eimeria acervulina (58\%), E. maxima (20\%), and E. tenella (22\%) in $1 \mathrm{ml}$ of sterile PBS via oral gavage. The concentration of the inoculum for each experiment was given as described above.

\section{OOCYST COUNTS AND LESION SCORING}

Prior to the beginning of the experiment, fecal samples from 5 birds/pen were collected to obtain a baseline measurement of Eimeria spp. infection. Coccidia oocysts were quantified by using the McMaster technique as previously described (Long and Rowell 1975). This procedure was performed at $14 \mathrm{~d}, 21 \mathrm{~d}$, and weekly during the experimental period. Intestinal lesion scoring was conducted in 2 birds/pen on the same days as oocyst counts using the scoring system developed by Johnson and Reid (1970).

\section{PLASMA XANTHOPHYLLS}

Starting at $21 \mathrm{~d}$, and then weekly for the duration of the study, $2 \mathrm{ml}$ of blood was collected from the wing veins of 3 birds per pen and mixed with EDTA in a 10:1 proportion. The test tubes were covered with aluminum foil to protect the blood samples from light, and stored in refrigeration for further measurement of plasma XA according to the method reported by Allen (1987).

\section{SKIN YELLOWNESS}

Starting at $21 \mathrm{~d}$, and then weekly for the duration of the study, skin yellowness units $\left(b^{*}\right)$ were determined in the right lateral apterial area of 10 birds/pen, using a reflectance colorimeter (Model CR-400, Minolta Corp., Ramsay, NJ.) (Muñoz-Díaz et al 2012).

\section{GROWTH PERFORMANCE}

All birds were weighed by pen at $21 \mathrm{~d}$ and $49 \mathrm{~d}$ of age. Feed intake was measured weekly to calculate BWG (g), feed consumption, pigment consumption, and feed conversion ratio (FCR).

\section{APPARENT ILEAL PIGMENT DIGESTIBILITY}

In Experiment 2, titanium dioxide was added to the diet at $0.2 \%$ and fed to the control and challenged birds from 28 to $35 \mathrm{~d}$ of age. At $35 \mathrm{~d}$ of age, 2 birds per pen were euthanized via $\mathrm{CO}_{2}$ asphyxiation and the ileal digesta was collected and frozen, freeze-dried, homogenised, and split into 2 subsamples for measurement of yellow XA by HPLC and titanium dioxide by spectrophotometry according to the methodology described by Ravindran et al (1999). A feed sample from control and challenged groups was collected and analysed for total XA and titanium dioxide.

\section{STATISTICAL ANALYSIS}

Growth performance, $b^{*}$, and plasma xanthophyll concentration were analyzed by ANOVA for a $4 \times 2$ factorial arrangement, where the first factor was the coccidia infection at 4 levels, and the second factor was sex at 2 levels. Data for ileal digestibility was analyzed using a $2 \times 2$ factorial arrangement in which the first factor was the infection level (non-infected or infected), and the second factor was the sex (males or females). Treatment means were compared by Tukey's multiple comparison procedure $(\mathrm{P}<0.05)$.

Data for skin and plasma pigmentation was fitted to a multiple regression model in which the independent variables were the time of pigment consumption and the coccidia infection level; sex was used as an indicative variable for which $0=$ females, and $1=$ males (Neter et al 1985). Oocyst fecal count data and the intestinal lesion scores were analyzed using the non-parametric KruskallWallis test. Treatment medians were compared by the Mann-Witney U test (Kuehl 2001).

\section{RESULTS}

\section{EXPERIMENT 1}

In Experiment 1, from 21 to $49 \mathrm{~d}$ of age, BWG in birds from the control group $(2,427 \mathrm{~g})$ was significantly greater than in birds from treatment $4(2,239 \mathrm{~g})$, which was challenged with the highest coccidia dose $(\mathrm{P}<0.05)$. The best FCR was observed in the birds from the control treatment $(1.96 \mathrm{~kg}: \mathrm{kg})$, which was significantly better from that observed in the treatment with the highest coccidia challenge $(2.22 \mathrm{~kg}: \mathrm{kg})$. As expected, there was a significant effect of sex on growth performance. In males, BWG $(2,538 \mathrm{~g})$, feed consumption $(5,110 \mathrm{~g})$ and pigment consumption $(434 \mathrm{mg})$ were significantly greater than in females (2,102 g, 4,589 g, $390 \mathrm{mg}$, respectively), while FCR was better in males $(2.01 \mathrm{~kg}: \mathrm{kg})$ when compared to the females $(2.18 \mathrm{~kg}: \mathrm{kg})$ (table 1$)$.

Between 0 and $28 \mathrm{~d}$ posinoculation ( 21 and $49 \mathrm{~d}$ of age), for every $\mathrm{d}$ that pigment was consumed, skin yellowness was increased by $1.36 \mathrm{~b} *$ for both males and females. However, the rate of skin pigmentation was greater in female birds $(1.94 \mathrm{~b} *)$. For every 10,000 SEO that birds received, skin pigmentation decreased by $0.06 \mathrm{~b} *$ (figure 1 ). This relationship can be described by the following equation: $b^{*}=2.08$ 
Table 1. Feed consumption, pigment consumption, body weight gain, feed conversion ratio, skin yellowness units (b*), and plasma xanthophylls of broiler chickens at $49 \mathrm{~d}$ of age infected with increasing doses of Eimeria spp. oocysts at $21 \mathrm{~d}$ of age, Experiment 1.

Consumo de alimento, consumo de pigmento, ganancia de peso, índice de conversión, amarilleamiento cutáneo (b*) y xantófilas plasmáticas de pollos de engorda de 49 días de edad, infectados con dosis ascendentes de ooquistes de Eimeria spp. al día 21 de edad, Experimento 1.

\begin{tabular}{|c|c|c|c|c|c|c|}
\hline $\begin{array}{c}\text { Treatment/ dose } \\
\text { of oocysts }\end{array}$ & $\begin{array}{l}\text { Feed consumption, } \\
\text { g/ bird }\end{array}$ & $\begin{array}{l}\text { Pigment consump- } \\
\text { tion, mg/bird }\end{array}$ & BW gain, g/ bird & FCR, kg:kg & $b^{*}$ & $\begin{array}{l}\text { Plasma xanthophylls, } \\
\mu \mathrm{g} / \mathrm{ml}\end{array}$ \\
\hline Control & $4,758^{\mathrm{a}}$ & $404^{\mathrm{a}}$ & $2,427^{\mathrm{a}}$ & $1.96^{\mathrm{b}}$ & $17.6^{\mathrm{a}}$ & $39.7^{\mathrm{a}}$ \\
\hline $8.32 \times 10^{4}$ & $4,764^{\mathrm{a}}$ & $405^{\mathrm{a}}$ & $2,293^{\mathrm{ab}}$ & $2.08^{\mathrm{ab}}$ & $13.1^{\mathrm{b}}$ & $25.5^{\mathrm{b}}$ \\
\hline $17.82 \times 10^{4}$ & $4,945^{\mathrm{a}}$ & $420^{\mathrm{a}}$ & $2,319^{\mathrm{ab}}$ & $2.13^{\mathrm{ab}}$ & $11.9^{\mathrm{b}}$ & $19.9^{\mathrm{b}}$ \\
\hline $49.92 \times 10^{4}$ & $4,932^{\mathrm{a}}$ & $419^{\mathrm{a}}$ & $2,240^{\mathrm{b}}$ & $2.22^{\mathrm{a}}$ & $13.8^{\mathrm{b}}$ & $25.6^{\mathrm{b}}$ \\
\hline SEM & 123 & 10.4 & 40.6 & 0.04 & 0.72 & 2.1 \\
\hline \multicolumn{7}{|l|}{ SEX } \\
\hline Males & 5,106 & 434 & 2,538 & 2.01 & 12.8 & 28.2 \\
\hline Females & 4,758 & 390 & 2,102 & 2.18 & 15.5 & 27.2 \\
\hline \multirow[t]{2}{*}{ SEM } & 87 & 7.4 & 28.7 & 0.03 & 0.51 & 1.5 \\
\hline & \multicolumn{6}{|c|}{ Probability } \\
\hline Treatment & NS & NS & $*$ & $*$ & $*$ & $*$ \\
\hline Sex & $*$ & $*$ & $*$ & $*$ & $*$ & NS \\
\hline Treatment X sex & NS & NS & NS & NS & NS & NS \\
\hline
\end{tabular}

Means with different superscripts within a same column differ significantly $(\mathrm{P}<0.05)$.

$*=(\mathrm{P}<0.05)$.

Medias con diferentes superíndices en una misma columna difieren significativamente $(\mathrm{P}<0,05)$.

$*=(\mathrm{P}<0,05)$.

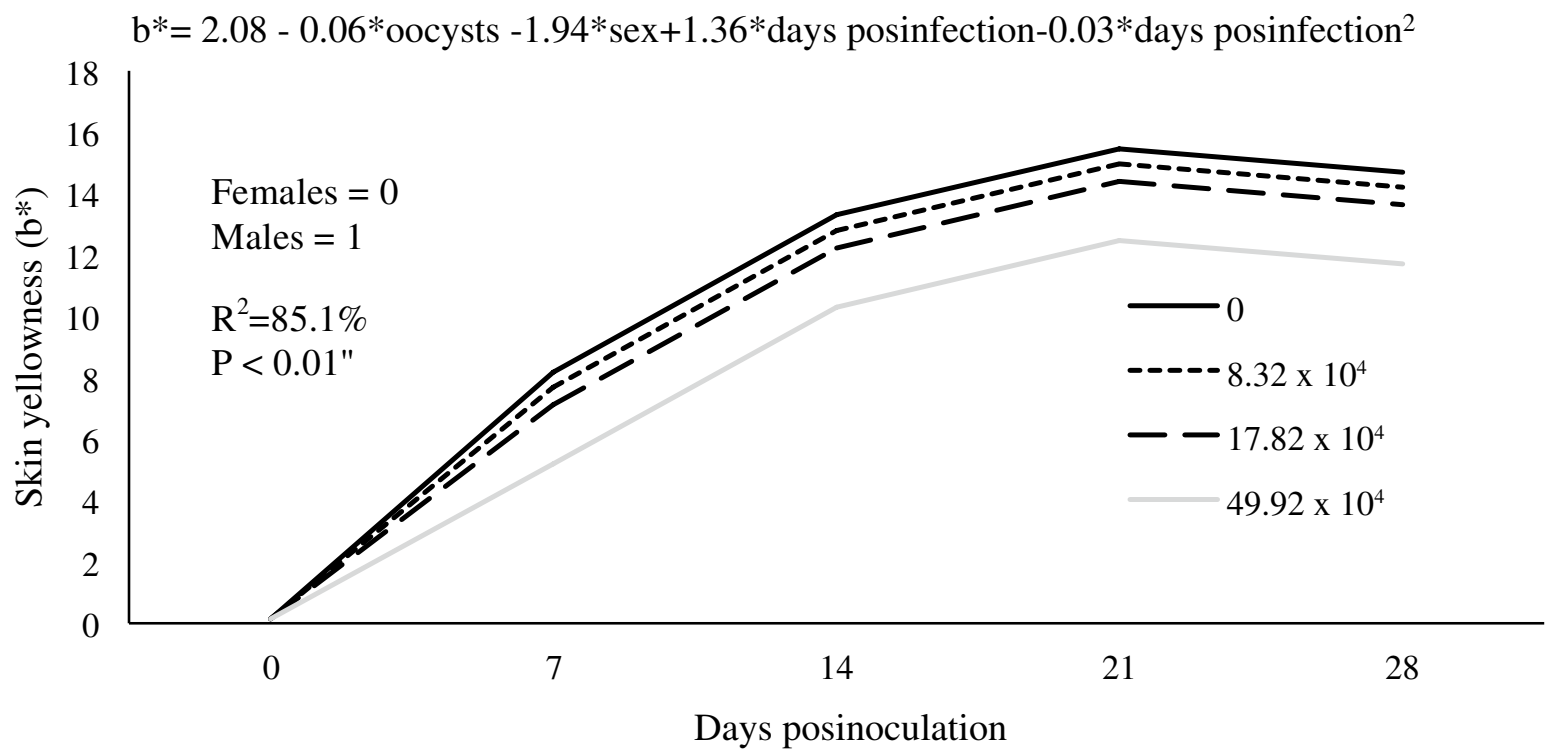

Figure 1. Skin yellowness units ( $\left.\mathrm{b}^{*}\right)$ in vivo from 0 to $28 \mathrm{~d}$ posinoculation ( 21 to $49 \mathrm{~d}$ of age) in broiler chickens infected with Eimeria spp. at $21 \mathrm{~d}$ of age and fed 85 ppm of dietary xanthophylls from Aztec marigold flower, Experiment 1.

Unidades de amarilleamiento cutáneo ( $\left.b^{*}\right)$ in vivo del día 0 al 28 posinoculación ( 21 a 49 días de edad) en pollos de engorda infectados con Eimeria spp. al día 21 de edad y alimentados con 85 ppm de xantófilas de flor de cempasúchil, Experimento 1.

- $0.06 *$ oocysts $-1.94 *$ sex $+1.36 *$ d post-infection $-0.03 * d$ post-infection ${ }^{2} ; \mathrm{R}^{2}=85.1 \% ; \mathrm{P}<0.01$. Skin yellowness (SY) in live birds at $49 \mathrm{~d}$ of age was significantly greater $(\mathrm{P}<0.05)$ in the control group $\left(17.6 \mathrm{~b}^{*}\right)$ with respect to treatments 2,3 , and $4\left(13.07,11.9\right.$ y $\left.13.8 b^{*}\right)$. SY in males was significantly lower than in females $(12.8 \mathrm{~b} *$ and 15.5 $b^{*}$, respectively) $(\mathrm{P}<0.05)$ (table 2$)$.

Concentration of PX was reduced by $0.8 \mu \mathrm{g} / \mathrm{ml}$ for every 10,000 SEO given to each bird. (figure 2). The effect of coccidia inoculation on PX concentration can be 
Table 2. Skin yellowness units $\left(b^{*}\right)$ and plasma xanthophyll concentration $(\mu \mathrm{g} / \mathrm{ml})$ in broiler chickens at $49 \mathrm{~d}$ of age after infection with increasing doses of Eimeria spp. oocysts at $21 \mathrm{~d}$ of age, Experiment 1.

Unidades de amarilleamiento cutáneo ( $b^{*}$ y concentración de xantófilas en plasma en pollos de engorda de 49 días de edad después de la infección con dosis ascendentes de Eimeria spp. al día 21 de edad, Experimento 1.

\begin{tabular}{|c|c|c|c|c|}
\hline \multicolumn{2}{|c|}{ Treatment / dose of oocysts } & Males & Females & Average \\
\hline \multicolumn{5}{|l|}{$\mathrm{b}^{*}$} \\
\hline 1. & Control & $16.4 \pm 1.02$ & $19.0 \pm 1.02$ & $17.6 \pm 0.72^{\mathrm{a}}$ \\
\hline 2. & $8.32 \times 10^{4}$ & $12.2 \pm 1.02$ & $14.0 \pm 1.02$ & $13.1 \pm 0.72^{b}$ \\
\hline 3. & $17.82 \times 10^{4}$ & $10.9 \pm 1.02$ & $12.9 \pm 1.02$ & $11.9 \pm 0.72^{\mathrm{b}}$ \\
\hline 4. & $49.92 \times 10^{4}$ & $11.7 \pm 1.02$ & $16.0 \pm 1.02$ & $13.8 \pm 0.72^{\mathrm{b}}$ \\
\hline Ave & & $12.8 \pm 0.51^{\mathrm{y}}$ & $15.5 \pm 0.51^{\mathrm{z}}$ & \\
\hline \multicolumn{5}{|c|}{ Plasma xanthophyll concentration $(\mu \mathrm{g} / \mathrm{ml})$} \\
\hline 1. & Control & $37.0 \pm 3.02$ & $42.9 \pm 3.02$ & $39.7 \pm 2.1^{\mathrm{a}}$ \\
\hline 2. & $8.32 \times 10^{4}$ & $25.4 \pm 3.02$ & $25.5 \pm 3.02$ & $25.5 \pm 2.1^{\mathrm{b}}$ \\
\hline 3. & $17.82 \times 10^{4}$ & $20.4 \pm 3.02$ & $19.4 \pm 3.02$ & $19.9 \pm 2.1^{\mathrm{b}}$ \\
\hline 4. & $49.92 \times 10^{4}$ & $29.8 \pm 3.02$ & $21.3 \pm 3.02$ & $25.6 \pm 2.1^{\mathrm{b}}$ \\
\hline \multicolumn{2}{|c|}{ Average } & $28.2 \pm 1.5^{\mathrm{z}}$ & $27.2 \pm 1.5^{z}$ & \\
\hline
\end{tabular}

Means \pm SE with different superscripts within a same column or arrow differ significantly $(\mathrm{P}<0.01)$.

Medias $\pm E E$ con diferentes superíndices en una misma columna o renglón difieren significativamente $(\mathrm{P}<0,01)$.

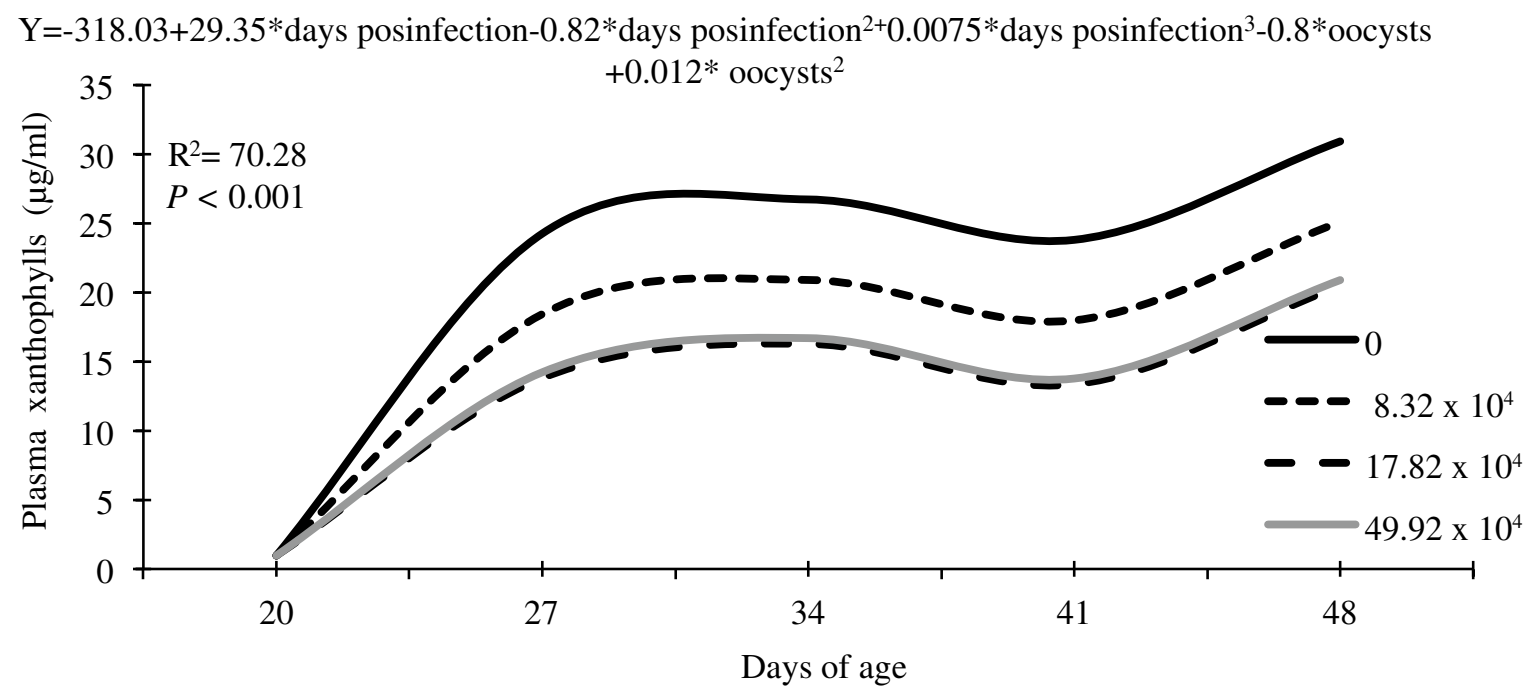

Figure 2. Plasma xanthophylls $(\mu \mathrm{g} / \mathrm{ml})$ in broiler chickens infected with Eimeria spp. at $21 \mathrm{~d}$ of age and fed 85 ppm of dietary xanthophylls from Aztec marigold flower from 21 to $49 \mathrm{~d}$ of age, Experiment 1.

Xantófilas plasmáticas $(\mu \mathrm{g} / \mathrm{ml})$ en pollos de engorda infectados con Eimeria spp. al día 21 de edad y alimentados con 85 ppm de xantófilas de flor de cempasúchil del día 21 al 49 de edad, Experimento 1.

explained by the following equation: $\mathrm{Y}=-318.03+29.35 * \mathrm{DI}-$ $0.82 * \mathrm{DI}^{2+} 0.0075 * \mathrm{DI}^{3}-0.8 *$ oei $+0.012 * \mathrm{SOE}^{2} ; \mathrm{R}^{2}=70.28$ : $\mathrm{P}<0.001$, in which $\mathrm{Y}=\mathrm{PX}$ concentration; $\mathrm{DI}=\mathrm{d}$ post-infection; SEO = sporulated Eimeria spp. oocysts inoculated. Results for PX concentration are presented in table 2. Birds from the unchallenged control treatment had significantly greater PX concentration $(39.7 \mu \mathrm{g} / \mathrm{ml})$ compared to the challenged treatments $(25.5,19.9$ and $25.6 \mu \mathrm{g} / \mathrm{ml}$ respectively). Sex had no significant effect on
PX concentration, and there were no interactions between treatments $(\mathrm{P}<0.05)$.

The oocyst count at the beginning of the study was negative for all treatments. After $21 \mathrm{~d}$ of age, the control treatment remained negative for oocysts. At $7 \mathrm{~d}$ post-inoculation, birds from treatment 4 had significantly greater oocyst counts medians $\left(16.14 \times 10^{4}\right.$ oocysts $\left./ g\right)$ with respect to treatments 2 or $3\left(2.42 \times 10^{4}\right.$ and $4.42 \times 10^{4}$ oocysts/g, respectively). At $14 \mathrm{~d}$ post-inoculation, there was a significant 
reduction in oocyst count in treatment 4 when compared to the previous week $\left(3.45 \times 10^{4}\right.$ oocysts/g). In this treatment, the oocyst count was lower than in treatment $3\left(6.98 \times 10^{4}\right.$ oocysts/g), but not different from treatment $2\left(2.88 \times 10^{4}\right.$ oocysts/g). At $21 \mathrm{~d}$ and $28 \mathrm{~d}$ post-inoculation, the oocyst counts were lower for treatment $2\left(1.08 \times 10^{4}\right.$ oocysts $\left./ g\right)$ with respect to treatment $4\left(3.96 \times 10^{4}\right.$ oocysts $\left./ g\right)$, but not different from treatment $3\left(2.31 \times 10^{4}\right.$ oocysts $\left./ g\right)(\mathrm{P}<0.05)$. The median of intestinal lesion scores in treatment 1 was zero, whereas for treatments 2, 3, or 4, the median lesion score was $1+$ or less, and no statistical difference was found between these treatments $(\mathrm{P}>0.05)$, (data not shown).

\section{EXPERIMENT 2}

Growth performance was not significantly different between treatments at $49 \mathrm{~d}$ of age. However, males had significantly higher feed consumption $(5,243 \mathrm{~g}), \mathrm{BWG}$ $(2,565 \mathrm{~g})$, and better FCR $(2.05 \mathrm{~kg}: \mathrm{kg})$ than females $(4,856$ $\mathrm{g}, 2,310 \mathrm{~g}$, and $2.1 \mathrm{~kg}: \mathrm{kg}$, respectively) $(\mathrm{P}<0.05)$. Pigment consumption was significantly greater in the males, and it differed across treatments according to the level of dietary XA. Birds from treatments 2, 3, and 4 received higher concentration of dietary XA from 35 to $49 \mathrm{~d}$ of age, and their XA consumption was 62, 178, and $223 \mathrm{mg}$ per bird greater than that observed in the birds from the control treatment (table 3).

SY was not different between treatments at $49 \mathrm{~d}$ of age (figure 3 ). Female birds had significantly greater skin yellowness $\left(23.72 b^{*}\right)$ than male birds $\left(21.47 b^{*}\right)$. PX concentration was not different between treatments at the end of the study (figure 4), and no significant effect of bird's sex was detected $(\mathrm{P}>0.05)$.

Apparent ileal XA digestibility was significantly reduced in the birds challenged with coccidia $(53.4 \%$ in males and $44.2 \%$ in females) in comparison with the control group (66.2\% in males and $61.3 \%$ in females). No effect of bird's sex was detected $(\mathrm{P}>0.05)$.

\section{DISCUSSION}

The reduction in BWG and increase in FCR observed in the birds challenged with the highest coccidia dose is in agreement with previous research findings. Infection with $E$. acervulina and E. maxima detrimentally affected growth performance 2 to 3 weeks after inoculation (Hein 1968, Preston-Mafham and Sykes 1970). This effect is related to the damage caused by the replication of the parasite in the intestine (Allen and Danforth 1984) that leads to poor digestion and absorption of nutrients (Ruff and Fuller 1975). As expected, the birds that received lower coccidia challenge doses showed intermediate values for BWG and FCR, due to the degree of damage associated with the lower dose of infective oocysts (Stephens et al 1967). In 9-d-old birds infected with $10^{5} \mathrm{E}$. acervulina oocysts, $6.7 \times 10^{3}$ E. maxima oocysts, and $10^{4}$ E. tenella oocysts, there was a significant reduction in BW at $5 \mathrm{~d}$ post-inoculation (Conway et al 1993).

The rate of XA absorption is affected by coccidia infections and it might not recover to normal levels for up to $20 \mathrm{~d}$ post-infection. Absorption of other nutrients like glucose might not recover to normal rates before 14

Table 3. Feed consumption, pigment consumption, body weight (BW) gain, and feed conversion ratio of broiler chickens fed increasing levels of dietary xanthophylls from 21 to $49 \mathrm{~d}$ of age and infected with Eimeria spp. oocysts at $21 \mathrm{~d}$ of age, Experiment 2.

Consumo de alimento, consumo de pigmento, ganancia de peso e índice de conversión, de pollos de engorda alimentados con niveles ascendentes de xantófilas del día 21 a 49 de edad, e infectados con ooquistes de Eimeria spp. al día 21 de edad, Experimento 2.

\begin{tabular}{lcccc}
\hline $\begin{array}{l}\text { Treatment (ppm of } \\
\text { xanthophylls) }\end{array}$ & Feed consumption, g/bird & BW gain, g/bird & Pigment consumption, mg/bird & FCR, kg:kg \\
\hline 85 & 5,044 & 2,499 & $428^{\mathrm{a}}$ & $2.023^{\mathrm{a}}$ \\
108 & 5,003 & 2,390 & $490^{\mathrm{b}}$ & $2.097^{\mathrm{a}}$ \\
141 & 5,128 & 2,404 & $606^{\mathrm{c}}$ & $2.133^{\mathrm{a}}$ \\
162 & 5,024 & 2,456 & $651^{\mathrm{d}}$ & $2.055^{\mathrm{a}}$ \\
SEM & 65.4 & 80.0 & 5.3 & 0.05 \\
Sex & & & & \\
Males & 5,243 & 2,565 & 566 & 2.052 \\
Females & 4,856 & 2,310 & 522 & 2.102 \\
SEM & 46.2 & 56.6 & 7.6 & 0.04 \\
Probability & & & $*$ & NS \\
Treatment & $\mathrm{NS}$ & $\mathrm{NS}$ & $*$ & $*$ \\
Sex & $*$ & $*$ & $\mathrm{NS}$ & $\mathrm{NS}$ \\
Treatment x Sex & $\mathrm{NS}$ & $\mathrm{NS}$ & & \\
\hline
\end{tabular}

Means with different superscripts within a column differ significantly $(\mathrm{P}<0.05)$.

Medias con diferentes superíndices en una misma columna difieren significativamente $(\mathrm{P}<0,05)$. 
Skin yellowness $\left(b^{*}\right)$

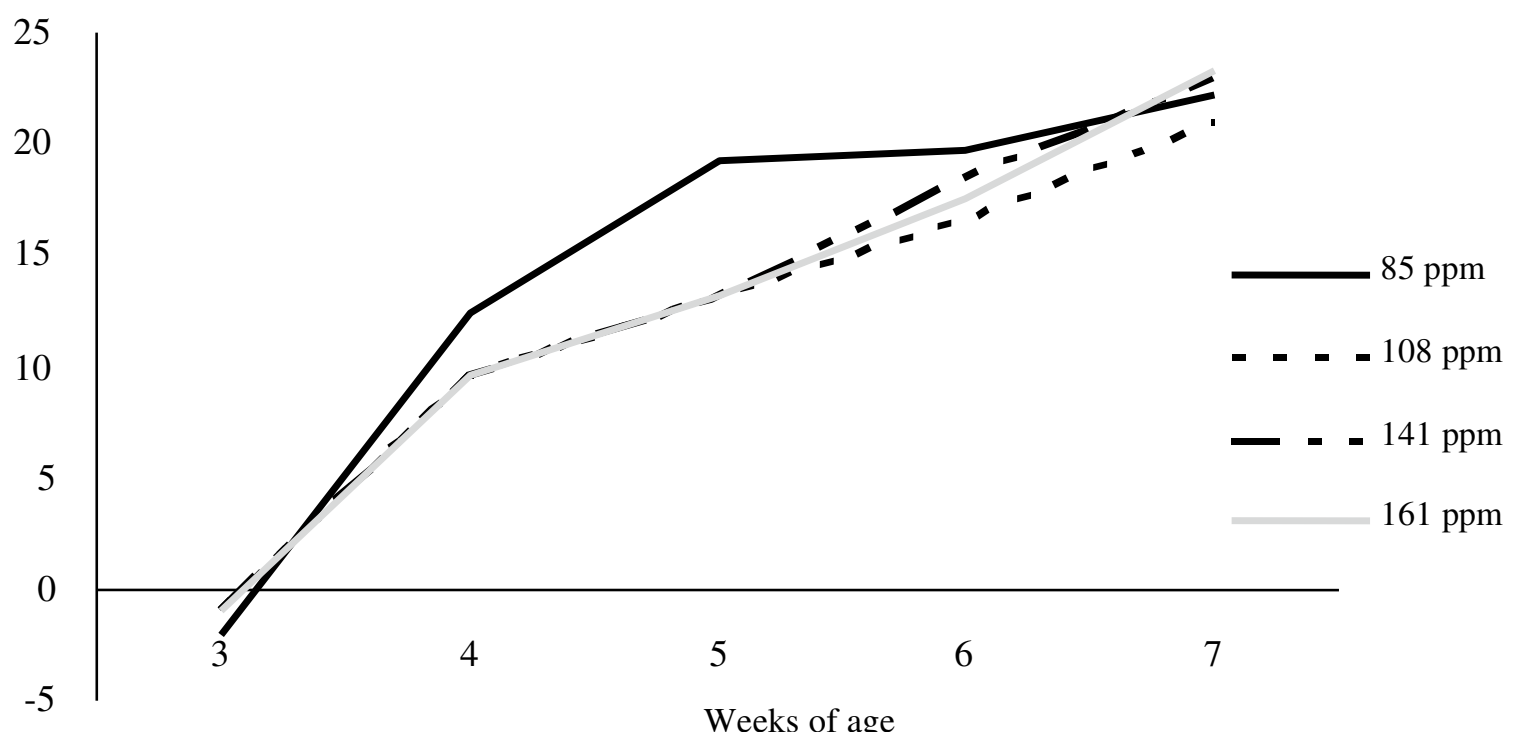

Figure 3. Skin yellowness units ( $\left.b^{*}\right)$ in broiler chickens challenged with 8.32 x $10^{4}$ oocysts of Eimeria spp. and fed increasing doses of xanthophylls, Experiment 2.

Unidades de amarilleamiento cutáneo ( $\left.\mathrm{b}^{*}\right)$ en pollos de engorda desafiados con 8,32 x $10^{4}$ ooquistes de Eimeria spp. y alimentados con dosis ascendentes de xantófilas, Experimento 2.

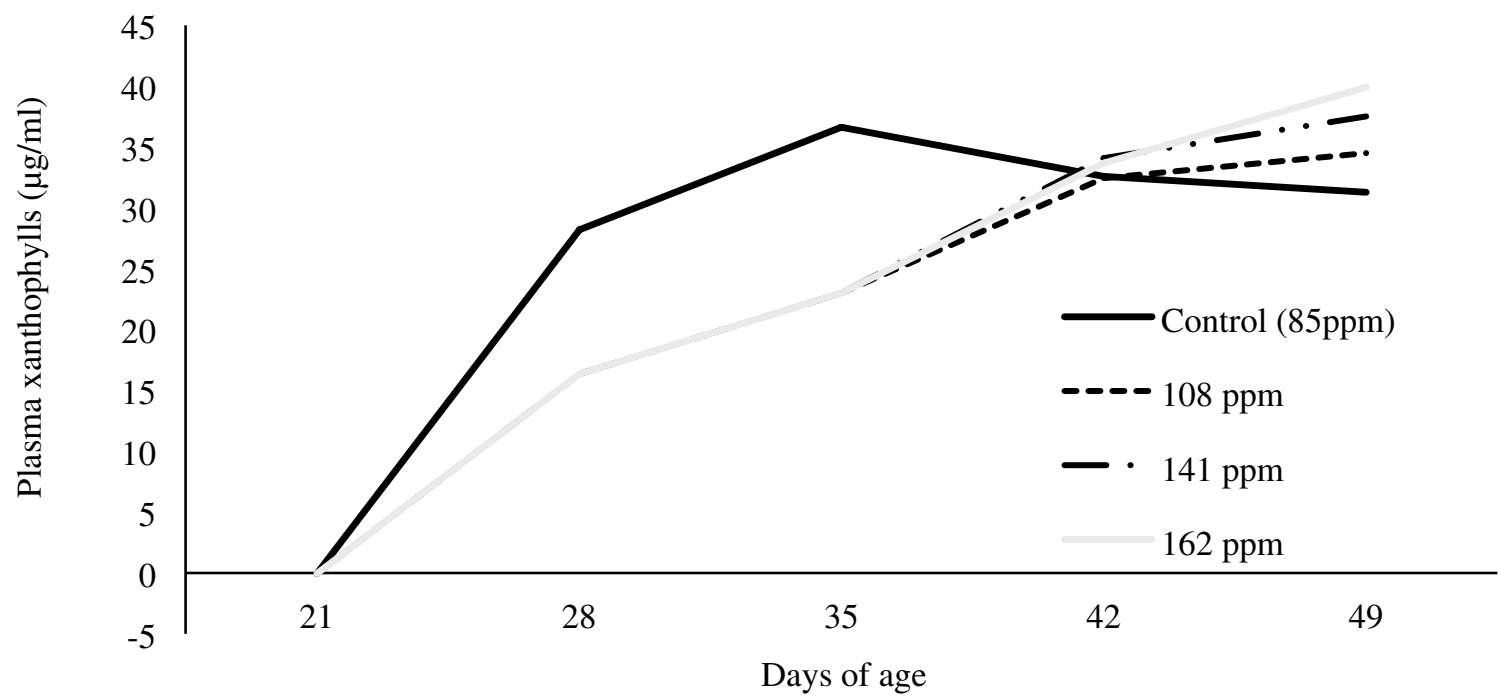

Figure 4. Plasma xanthophylls $(\mu \mathrm{g} / \mathrm{ml})$ in broiler chickens challenged with $8.32 \times 10^{4}$ sporulated Eimeria spp. oocysts, treated with a coccidiostat, and fed high doses of xanthophylls, Experiment 2.

Xantófilas plasmáticas $(\mu \mathrm{g} / \mathrm{ml})$ en pollos de engorda desafiados con $8,32 \times 10^{4}$ ooquistes esporulados de Eimeria spp. tratados con un coccidiostato, y alimentados con dosis ascendentes de xantófilas, Experimento 2.

d post-infection (Ruff and Wilkins 1980), thus birds may recover their BWG before they regain skin pigmentation after a coccidia infection. This could explain why birds from treatments 2 and 3 had better BWG than treatment 4 . Nevertheless, none of the birds from the infected treatments achieved the same skin pigmentation observed in the non-challenged birds.
In Experiment 1, the reduction in skin pigmentation in birds challenged with coccidia was due to the reduction in the absorption of pigment, mainly caused by E. acervulina and E. maxima. Both Eimeria species produce villi sloughing and shortening in the intestinal regions where most of the pigment absorption occurs. On the other hand, E. tenella may induce a mild but continuous decrease in 
plasma carotenoids due to the blood loss associated with the damage in the cecal epithelium (McDougald and FitzCoy 2008). At the end of the study, SY was similar in all treatments, and the only difference was due to bird's sex. The female birds had significantly higher skin pigmentation, even though the males showed greater pigment consumption. This finding is in agreement with the reports by Sirri et al (2010) and Muñoz-Díaz et al (2012) and it is attributed to higher deposition of subcutaneous fat in the females, which is related to genetic and hormonal factors (Le Bihan-Duval et al 1998, Rance et al 2002).

In both experiments there was a reduction in PX concentration at 8 and $13 \mathrm{~d}$ post-infection, which has been reported previously (Juárez et al 2002). This might be due to the greater quantities of merozoites and gametocytes in the intestinal mucosa during this post-infection period (McDougald and Fitz-Coy 2008) that detrimentally influence XA absorption. The reduction in plasma carotenoids in birds infected with Eimeria spp. might also be related with a decline in the synthesis of Apo-I and Apo-III proteins by the enterocyte. These proteins have a major role in the transport of pigment to the liver and other tissues (Allen 1987). Furthermore, E. acervulina reduced the intestinal $\mathrm{pH}$, which negatively affects pigment absorption (Kouwenhoven and van der Host 1969).

The highest PX concentration was found at $29 \mathrm{~d}$ of pigment consumption in all treatments. This is in agreement with Tepox (2013), who measured the highest PX concentrations after $28 \mathrm{~d}$ of consumption of dietary XA concentrations between 65 and 200ppm.

In Experiment 1, the number of oocysts shed through feces in the birds challenged with the highest infective dose $\left(49.92 \times 10^{4} \mathrm{SOE}\right)$ peaked at $7 \mathrm{~d}$ post-inoculation, and declined rapidly afterwards. A similar trend was observed in the intestinal lesions (gross white plaques) caused by $E$. acervulina for the same treatment. Such a reduction in oocyst shedding might be due to faster development of immunity in response to a more severe challenge. Therefore, the severity of intestinal lesions and oocyst shedding diminished rapidly. On the other hand, the birds challenged with lower oocyst doses required longer time to develop immunity, thus prolonging oocyst shedding. This could explain why the birds challenged with the intermediate oocyst doses had the highest oocyst shedding counts at $21 \mathrm{~d}$ post-infection.

In Experiment 1, there was no significant difference in the intestinal lesion scores, which were compatible with a subclinical infection according to the scale described by Johnson and Reid (1970). Although intestinal lesion scores have been used over the years to assess the degree of damage by coccidia infections both experimentally and under field situations, there seems to be no correlation between the degree of infection or the number of oocysts inoculated or shed through feces (Conway et al 1990, Kogut and Powell 1993).

Mild or subclinical Eimeria spp. infections are not easily detectable since they do not induce clear negative effects on growth performance. In countries where pigmented chicken is produced, subclinical coccidia infections are suspected only based on substandard skin pigmentation. Various studies have demonstrated that levels of plasma carotenoids and skin pigmentation are excellent response variables to evaluate coccidia infections due to the sensitivity of these measurements to the disease (Ruff and Fuller 1975, Sharma and Fernando 1975). In this study these parameters were confirmed to be very good indicators of physiological intestinal integrity (Conway et al 1993).

Broiler chickens can reach adequate skin pigmentation levels if higher concentrations of dietary XA are fed for $14 \mathrm{~d}$ prior to slaughter age (Muñoz-Díaz et al 2012). In Experiment 2, even though the birds were infected with Eimeria spp., they were able to recover the expected SY after being treated with an anticoccidial drug, and fed with at least $62 \mathrm{mg}$ of XA/bird from 35 to $49 \mathrm{~d}$ of age. It is possible that this effect might have been influenced by the high enterocyte turnover rate. During mild coccidia infections ( $1 \times 10^{5}$ E. acervulina oocysts per bird), the acute phase (4-8 d post-infection) is characterized by a sharp drop in absorption and deposition of pigment, and a recovery phase from 9 to $14 \mathrm{~d}$ post-infection (Sharma and Fernando 1975). Regeneration of intestinal epithelium occurs rapidly during mild coccidia infections and can be completed by $10 \mathrm{~d}$ post-infection (McDougald and Fitz-Coy 2008). Our results suggest that if the coccidia infection is controlled, and the birds received prompt anticoccidial treatment, absorption capacity and skin deposition of pigment may be fully recovered (Mathis et al 2004). In adition, feeding very high concentrations of dietary XA sometimes does not result in a significant increase of SY but results in a waste of XA.

No difference was detected in apparent ileal pigment digestibility between males and females, which is in agreement with previous research reported elsewhere (Tepox 2013). The results of the current study suggest that pigment is absorbed in a similar rate in males and females. However, pigment deposition seems to be more efficient in females. In the study reported herein, pigment digestibility was reduced by 15 percent in birds challenged with coccidia with respect to unchallenged birds. Although digestibility of carbohydrates, protein, and amino acids in chickens has been vastly evaluated (Yutste et al 1991, Ravindran et al 1999, Lemme et al 2004), to the author's knowledge, pigment digestibility has not been reported before, especially as influenced by coccidia infections.

Pigmentation measurements could be helpful tools to determine the virulence of Eimeria species and strains. It would be necessary to conduct further studies to evaluate the effect of other Eimeria strains on these measurements to determine their limitations or benefits as compared to other criteria commonly used to determine the pathological effects of Eimeria infections such as oocyst counts and lesion scoring. 


\section{REFERENCES}

Allen CP, HD Danforth. 1984. The effects of Eimeria acervulina infection on the metabolism of chick duodenal tissue. Vet Parasitol 14, 105-115.

Allen CP. 1987. Physiological of chicken gut tissue to coccidial infection: comparative effects of Eimeria and Eimeria acervulina and Eimeria mitis on mucosal mass, carotenoid content and brush border enzyme activity. Poult Sci 66, 1306-1315.

Baker R, C Günther. 2004. The role of carotenoids in consumer choice and the likely benefits from their inclusion into products for human consumption. Trends Food Sci Technol 15, 484-488.

Breithaupt DE. 2007. Modern application of xanthophylls in animal feeding, a review. Trends Food Sci Technol 18, 501-506.

Britton G, S Liaen-Jensen, H Pfander. 1998. Carotenoids: Biosynthesis and Metabolism. Birkhâuser, Berlin, Germany, Pp 29-37.

Conway DP, ME McKenzie, AD Dayton. 1990. Relationship of coccidian lesion scores and weight gain infection of Eimeria. Avian Pathol $19,489-496$.

Conway DP, K Sasai, SM Gaafar, CN Herbert. 1993. Effects of different levels of oocyst inocula of Eimeria acervulina, E. tenella and $E$. maxima on plasma constituents, packed cell volume, lesion scores and performance in chickens. Avian Dis 37, 118-123.

Hadden WL, RH Watkins, LW Levy, E Regalado, DM Rivadeneira, RB Van Breemen, SJ Schwartz. 1999. Carotenoid composition of Marigold (Tagetes erecta) flower extract used as nutritional supplement. J Agric Food Chem 47, 4189-4194.

Hein H. 1968. The patogenic effects of Eimeria acervulina in young chicks. Exp Parasitol 22, 1-11.

Hernandez-Velasco X, HD Chapman, CM Owens, VA Kuttappan, B Fuente-Martinez, A Menconi, JD Latorre, G Kallapura, LR Bielke, T Rathinam, BM Hargis, G Tellez. 2014. Absorption and deposition of xanthophylls in broilers challenged with three doses of Eimeria acervulina oocysts. Br Poult Sci 55, 167-173.

Idris AB, DI Bounous, MA Woodwin, J Brown, EA Krushinskie. 1997. Quantitative pathology of small intestinal coccidiosis causal by Eimeria maxima in young broilers. Avian Pathol 26, 731-737.

Johnson J, WM Reid. 1970. Anticoccidial drugs: lesion scoring techniques in battery and floor-pen experiments with chickens. Exp Parasitol $28,30-36$

Juárez RM. 2002. Efecto de varios agentes sobre la pigmentación cutánea. Tesis de licenciatura, Facultad de Medicina Veterinaria y Zootecnia, Universidad Nacional Autónoma de México, DF, México.

Kijlstra A, Y Tian, ER Kelly, TT Berendscot. 2012. Lutein: more than just a filter for blue light. Prog Retin Eye Res 31, 303-315.

Kogut MH, KC Powell. 1993. Preliminary findings of alteration in serum alkaline phosphatase activity in chickens during coccidial infection. J Com Pathol 108, 113-119.

Kotake-Nara E, A Nagao. 2011. Absorption and metabolism of xanthophylls. Mar Drugs 9, 1024-1037.

Kouwenhoven B, CJ van der Horst. 1969. Strongly acid intestinal content and lowered protein, carotene and vitamin A blood levels in Eimeria acervulina infected chickens. Z Parasitenkd 32, 347-353.

Kuehl R. 2001. Diseño de experimentos: Principios estadísticos de diseño y análisis de investigación. $2^{\mathrm{a}}$ ed. Universidad de Arizona, Tucson, Arizona, EE.UU., Pp 120-145.

Le Bihan-Duval E, S Mignon-Grasteau, N Millet, C Beaumont. 1998. Genetic analysis of a selection experiment on increased body weight and breast muscle weight as well as on limited abdominal fat weight. Br Poult Sci 39, 346-353.
Lemme A, V Ravindran, WL Bryden. 2004. Ileal digestibility of amino acid in feed ingredients for broilers. World's Poult Sci J 60, 423-438.

Liu GD, GY Hou, DJ Wang, SJ Lv, XY Zhang, WP Sun, Y Yang. 2008. Skin pigmentation evaluation in broilers fed different levels of natural okra and synthetic pigments. J Appl Poult Res 17, 498-504.

Long PL, JG Rowell. 1975. Sampling broiler house litter for coccidial oocysts. Br Poult Sci 16, 583-592.

Mathis GF, RD Froyman, T Kennedy. 2004. Coccidiosis control by administering the drinking water for a 2-day period. Vet Parasitol 121, 1-9.

McDougald LR, SH Fitz-Coy. 2008. Coccidiosis. In: Saif YM, Fadly AM, Glisson JR, McDougald LR, Nolan LK, Swayne DE (eds). Diseases of Poultry. $12^{\text {th }}$ ed. Blackwell Publishing, Ames, Iowa, USA, Pp 1068-1080.

Muñoz-Díaz JI, B Fuente-Martínez, X Hernández-Velasco, E ÁvilaGonzález. 2012. Skin pigmentation in broiler chickens fed various levels of metabolizable energy and xanthophylls from Tagetes erecta. J Appl Poult Res 21, 788-796.

Neter J, W Wasserman, MH Kutner. 1985. Applied Linear Statistical Models. Richard D Irwin Inc., Homewood, Illinois, USA. New York, USA, Pp 120-145.

Ogbuokiri UDE, SA Edgar. 1986. Effect of mild infections with six species of Eimeria on skin pigmentation of broiler chickens. Poult Sci 65, 1816-1818.

Preston-Mafham RA, AH Sykes. 1970. Changes in body weight and intestinal absorption during infections with Eimeria acervulina in the chicken. Parasitol 61, 417-424.

Rance KA, GM McEntee, RM McDevitt. 2002. Genetic and phenotypic relationships between and within support and demand tissues in a single line of broiler chicken. Br Poult Sci 43, 518-527.

Ravindran V, LI Hew, G Ravindran, WL Bryden. 1999. A comparison of ileal digesta and excreta analysis for the determination of amino acid digestibility in food ingredients for poultry. Br Poult Sci 40, 266-274.

Ruff MD, HL Fuller. 1975. Some mechanisms of reduction of carotenoid levels in chickens infected with Eimeria acervulina or E. tenella. J Nutr 105, 1447-1456.

Ruff MD, GC Wilkins. 1980. Total intestinal absorption of glucose and I-metionina in broilers infected with E. acervulina, E. mivati, E. maxima, E. bruneti. Parasitol 80, 550-559.

Sharma VD, MA Fernando. 1975. Effect of Eimeria acervulina infection on nutrient retention with special reference to fat malabsorption in chickens. Can J Comp Med 39, 146-154.

Sirri F, M Petracci, M Bianchi, A Meluzzi. 2010. Survey of skin pigmentation of yellow-skinned broiler chickens. Poult Sci 89, 1556-1561.

Stephens JF, LM Kowalski, WJ Borst. 1967. Some physiological effects of coccidiosis caused by Eimeria maxima in young chickens. $J$ Parasitol 53, 176-179.

Tepox PM. 2013. Absorción, depósito y eliminación de pigmento con diferentes programas de adición de xantófilas en dietas de pollo de engorda. Tesis de maestría, Facultad de Medicina Veterinaria y Zootecnia, Universidad Nacional Autónoma de México, México DF, México.

Tyczkowski JK, PB Hamilton. 1991. Altered metabolism of carotenoids during pale-bird syndrome in chickens infected with Eimeria acervulina. Poult Sci 70, 2074-2081.

Yutste P, MA Longstaff, JM McNab, C McCorquodale. 1991. The digestibility of semipurified from wheat, cassasova, pea, bean and potato by adult cockerels and young chicks. Anim Feed Sci Technol $35,289-300$. 
